\title{
Reductive N-N Bond Cleavage of Diphenylhydrazine and Azobenzene Induced by Coordinatively Unsaturated $\mathrm{Cp} * \mathrm{Fe}\left\{\mathrm{N}\left(\mathrm{SiMe}_{3}\right)_{2}\right\}$
}

\author{
Yasuhiro Ohki*, Yuko Takikawa, Tsubasa Hatanaka, and Kazuyuki Tatsumi* \\ Department of Chemistry, Graduate School of Science and Research Center for Materials Science, \\ Nagoya University, Furo-cho, Chikusa-ku, Nagoya 464-8602, Japan
}

Supporting Information

General Procedures. All compounds were manipulated using standard Schlenk and vacuum line techniques or a glove box under nitrogen atmosphere. Toluene and hexane were purified by the method of Grubbs, where the solvents were passed over columns of activated alumina and supported copper catalyst supplied by Hansen \& Co. Ltd. Hexamethyldisiloxane was distilled from sodium benzophenone ketyl. $\quad \mathrm{C}_{6} \mathrm{D}_{6}$ was dried by sodium and distilled prior to use. $\quad{ }^{1} \mathrm{H}$ NMR and ${ }^{13} \mathrm{C}\left\{{ }^{1} \mathrm{H}\right\}$ NMR spectra were recorded on a Varian INOVA-500 or a JEOL ECA-600. The signals were referenced to the residual proton peak of $\mathrm{C}_{6} \mathrm{D}_{6}$. Elemental analyses were recorded on a LECO-CHNS-932 elemental analyzer where the crystalline samples were sealed in silver capsules under nitrogen. X-ray diffraction data were collected on a Rigaku AFC8 or a Rigaku RA-Micro7 equipped with a CCD area detector by using graphite-monochromated MoK $\alpha$ radiation. $\mathrm{Cp} * \mathrm{Fe}\left\{\mathrm{N}\left(\mathrm{SiMe}_{3}\right)_{2}\right\}$ (1) was prepared according to the literature procedure. ${ }^{1}$

\section{$\mathrm{Cp}_{2}{ }_{2} \mathrm{Fe}_{2}(\mu-\mathrm{NMePh})_{2}(2)$}

To a toluene $(10 \mathrm{~mL})$ solution of $\mathrm{Cp} * \mathrm{Fe}\left\{\mathrm{N}\left(\mathrm{SiMe}_{3}\right)_{2}\right\}(0.151 \mathrm{~g}, 0.43 \mathrm{mmol})$ was added methylaniline $(46 \mu \mathrm{L}, 0.42 \mathrm{mmol})$ at $-40{ }^{\circ} \mathrm{C}$, and the mixture was stirred at room temperature for 5 h. The resultant greenish brown solution was evaporated to dryness. The crude product was extracted with toluene and centrifuged. The solvent was removed under vacuum, and the residue was washed with hexane to afford a greenish brown powder of $\mathrm{Cp}_{2}{ }_{2} \mathrm{Fe}_{2}(\mu-\mathrm{NMePh})_{2}(2)(101 \mathrm{mg}$, $0.34 \mathrm{mmol}, 79 \%)$. X-ray quality crystals were grown from toluene/hexane at $-10{ }^{\circ} \mathrm{C}(65 \mathrm{mg}, 0.22$ mmol, $51 \%) . \quad{ }^{1} \mathrm{H}$ NMR (600 MHz, $\left.\mathrm{C}_{6} \mathrm{D}_{6}, \mathrm{rt}\right): \delta 91.61$ (15H, Cp*), $71.96(3 \mathrm{H}, \mathrm{NMePh}),-28.79$ 
$(2 \mathrm{H}, \mathrm{Ph}),-33.59(2 \mathrm{H}, \mathrm{Ph}),-87.89(1 \mathrm{H}, \mathrm{Ph})$. Anal. Calcd for $\mathrm{C}_{34} \mathrm{H}_{46} \mathrm{Fe}_{2} \mathrm{~N}_{2}: \mathrm{C}, 68.70 ; \mathrm{H}, 7.80 ; \mathrm{N}$, 4.71. Found: C, 68.61; H, 7.45; N, 4.63.

\section{$\mathrm{Cp}_{2}{ }_{2} \mathrm{Fe}_{2}(\mu-\mathrm{NPh})_{2}(3)$}

To a toluene $(20 \mathrm{~mL})$ solution of $\mathrm{Cp} * \mathrm{Fe}\left\{\mathrm{N}\left(\mathrm{SiMe}_{3}\right)_{2}\right\}(0.159 \mathrm{~g}, 0.45 \mathrm{mmol})$ was added diphenylhydrazine $(41 \mathrm{mg}, 0.22 \mathrm{mmol})$ at $-40{ }^{\circ} \mathrm{C}$, and the mixture was stirred at room temperature for $3 \mathrm{~h}$. The solvent was removed under reduced pressure, and the resultant brown solid was washed with cold hexamethyldisiloxane $(3 \mathrm{~mL}$ x 2$)$. The residue was extracted with hexane and centrifuged. The solvent was removed under vacuum to afford a brown powder of $\mathrm{Cp}^{*}{ }_{2} \mathrm{Fe}_{2}(\mu-\mathrm{NPh})_{2}(3)(74 \mathrm{mg}, 0.26 \mathrm{mmol}, 58 \%)$. X-ray quality crystals were grown from hexane at $-40{ }^{\circ} \mathrm{C}(52 \mathrm{mg}, 0.18 \mathrm{mmol}, 40 \%) . \quad{ }^{1} \mathrm{H} \mathrm{NMR}\left(600 \mathrm{MHz}, \mathrm{C}_{6} \mathrm{D}_{6}, \mathrm{rt}\right): \delta 2.46(\mathrm{~s}, 15 \mathrm{H}, \mathrm{Cp} *), 6.58(\mathrm{~d}$, $J=7.3 \mathrm{~Hz}, 2 \mathrm{H}, \mathrm{Ph}), 7.22(\mathrm{t}, J=7.3 \mathrm{~Hz}, 1 \mathrm{H}, \mathrm{Ph}), 7.93(\mathrm{t}, J=7.3 \mathrm{~Hz}, 2 \mathrm{H}, \mathrm{Ph}) .{ }^{13} \mathrm{C}\left\{{ }^{1} \mathrm{H}\right\} \mathrm{NMR}(125$ $\left.\mathrm{MHz}, \mathrm{C}_{6} \mathrm{D}_{6}, \mathrm{rt}\right): \delta 5.1\left(\mathrm{C}_{5} M e_{5}\right), 100.0\left(C_{5} \mathrm{Me}_{5}\right), 123.4(\mathrm{Ph}), 129.1(\mathrm{Ph}), 134.6(\mathrm{Ph}), 164.8(\mathrm{Ph})$. Anal. Calcd for $\mathrm{C}_{32} \mathrm{H}_{40} \mathrm{Fe}_{2} \mathrm{~N}_{2}$ : C, 68.10; H, 7.14; N, 4.96. Found: C, 68.21; H, 6.87; N, 5.04.

\section{$\mathrm{Cp}_{2}{ }_{2} \mathrm{Fe}_{2}(\mu-\mathrm{H})\left\{\mu-\mathrm{N}\left(\mathrm{SiMe}_{3}\right)_{2}\right\}(4)$}

To a hexane $(5 \mathrm{~mL})$ solution of $\mathrm{Cp} * \mathrm{Fe}\left\{\mathrm{N}\left(\mathrm{SiMe}_{3}\right)_{2}\right\}(0.517 \mathrm{~g}, 1.47 \mathrm{mmol})$ was added 4,4,5,5,-tetramethyl-1,3,2-dioxaborolane $(107 \mu \mathrm{L}, 0.74 \mathrm{~mol})$ at $-80{ }^{\circ} \mathrm{C}$. The reaction mixture was allowed to warm up to ambient temperature and stirred for $4 \mathrm{~h}$. The solvent was removed under vacuum, and the resultant dark brown residue was extracted with $20 \mathrm{~mL}$ of hexamethyldisiloxane. After centrifugation, the extract was concentrated to ca. $5 \mathrm{~mL}$ under reduced pressure. The concentrated solution was placed into a freezer at $-40{ }^{\circ} \mathrm{C}$, and $98 \mathrm{mg}(0.18 \mathrm{mmol}, 24 \%)$ of $\left(\mathrm{Cp}^{*} \mathrm{Fe}\right)_{2}\left\{\mu-\mathrm{N}\left(\mathrm{SiMe}_{3}\right)_{2}\right\}(\mu-\mathrm{H})(4)$ was isolated as dark brown crystals. ${ }^{1} \mathrm{H}$ NMR $\left(500 \mathrm{MHz}, \mathrm{C}_{6} \mathrm{D}_{6}\right.$, rt): $\delta-1.30\left(\mathrm{~s}, 18 \mathrm{H}, \mathrm{SiMe}_{3}\right),-5.13(\mathrm{~s}, 30 \mathrm{H}, \mathrm{Cp} *) .{ }^{13} \mathrm{C}\left\{{ }^{1} \mathrm{H}\right\}$ NMR $\left(125 \mathrm{MHz}, \mathrm{C}_{6} \mathrm{D}_{6}, \mathrm{rt}\right): \delta 75.42$, -11.52, -175.5. Anal. Calcd for $\mathrm{C}_{26} \mathrm{H}_{49} \mathrm{Fe}_{2} \mathrm{~N}_{1} \mathrm{Si}_{2}$ C,57.45; H, 9.09; N, 2.58. Found: C, 56.11; H, $8.78 ; \mathrm{N}, 2.20$.

Reaction of 1 with Pinacolborane and Azobenzene. $\mathrm{A} \mathrm{C}_{6} \mathrm{D}_{6}$ solution $(2.0 \mathrm{~mL})$ of $\mathbf{1}(200 \mathrm{mg}$, $0.57 \mathrm{mmol}$ ) and azobenzene $(52 \mathrm{mg}, 0.29 \mathrm{mmol}$ ) was charged into an NMR tube. After addition of hexamethylbenzene (46 mg, $0.29 \mathrm{mmol}$ ) as the internal standard, the solution was frozen. To this mixture was added pinacolborane $(66 \mu \mathrm{L}, 0.45 \mathrm{mmol})$. The NMR tube was sealed and 
gradually warmed to ambient temperature, during which the color of the solution turned to dark brown. Then a part of the solution was removed from the NMR tube to leave ca. $0.5 \mathrm{~mL}$. The resulting ${ }^{1} \mathrm{H}$ NMR spectrum revealed the formation of $3(29 \%), 4(17 \%)$, and $\mathrm{Cp}^{*}{ }_{2} \mathrm{Fe}(25 \%)$ based on the internal standard.

X-ray Structural Determination. Crystal data and refinement parameters of 2, 3, and 4 are summarized in Table S1. Single crystals were coated with oil (Immersion Oil, type B: Code 1248, Cargill Laboratories, Inc.) and mounted on loops. Diffraction data were collected on a Rigaku Mercury CCD diffractometer (for 2) and Rigaku Saturn 70 CCD with Micromax (for 3 and 4), equipped with a graphite monochromatized MoKa source $(\lambda=0.71070 \AA)$. Data were collected on 720 oscillation images with oscillation range of $0.5^{\circ}$. The frame data were integrated using the CrystalClear program package, and the data sets were corrected for absorption using a REQAB program. The calculations were performed with a TEXSAN program package. The structure was solved by a direct method (SIR-92), and was refined by full-matrix least squares. Anisotropic refinement was applied to all non-hydrogen atoms except for the disordered atoms, and all hydrogen atoms except for the bridging hydride in $\mathbf{3}$ (positionally refined) were put at the calculated positions. The $\mathrm{C}_{5} \mathrm{Me}_{5}$ groups in one of the two independent $\mathbf{2}$ are disordered over two positions, which was refined in the ratio of 50:50. Completeness of the diffraction data for 2 is 0.96 due to the small crystal size which results in low intensities for the diffractions appeared in higher $\theta$ range.

Table S1. Crystal data and structure refinement for 2-4

\begin{tabular}{|c|c|c|c|}
\hline & 2 & 3 & 4 \\
\hline Formula & $\mathrm{C}_{34} \mathrm{H}_{46} \mathrm{~N}_{2} \mathrm{Fe}_{2}$ & $\mathrm{C}_{16} \mathrm{H}_{20} \mathrm{NFe}$ & $\mathrm{C}_{26} \mathrm{H}_{49} \mathrm{NSi}_{2} \mathrm{Fe}_{2}$ \\
\hline Fw & 594.44 & 292.27 & 543.54 \\
\hline Crystal system & Triclinic & monoclinic & orthrhombic \\
\hline Temperature $\left({ }^{\circ} \mathrm{C}\right)$ & -100 & -130 & -130 \\
\hline Space group & P-1 (\#2) & C2/c (\#15) & Fddd (\#70) \\
\hline$a(\AA)$ & $10.349(8)$ & 17.794(3) & 20.681(3) \\
\hline$b(\AA)$ & $12.101(4)$ & $11.639(2)$ & 22.191(3) \\
\hline$c(\AA)$ & $12.420(3)$ & $13.517(2)$ & $25.607(3)$ \\
\hline$\alpha\left({ }^{\circ}\right)$ & $91.378(10)$ & & \\
\hline$\beta\left(^{\circ}\right)$ & $90.12(6)$ & $93.709(2)$ & \\
\hline$\gamma\left(\left(^{\circ}\right)\right.$ & $99.34(4)$ & & \\
\hline$V\left(\AA^{3}\right)$ & $1534.3(14)$ & 2793.6(7) & $11751.4(2)$ \\
\hline $\mathrm{Z}$ & 2 & 8 & 16 \\
\hline$D_{\text {calcd }}\left(\mathrm{g} / \mathrm{cm}_{3}\right)$ & 1.287 & 1.390 & 1.229 \\
\hline
\end{tabular}




\begin{tabular}{llll}
$\mu(\mathrm{Mo} \mathrm{Ka})\left(\mathrm{cm}^{-1}\right)$ & 9.69 & 10.62 & 10.81 \\
Max $2 \theta\left(^{\circ}\right)$ & 55.0 & 55.0 & 55.0 \\
no of data collected & 6745 & 3184 & 3377 \\
no of unique data with $[\mathrm{I}>0 \sigma(\mathrm{I})]$ & 6568 & 3151 & 3361 \\
no. of params refined & 364 & 163 & 142 \\
$R$ & 0.097 & 0.030 & 0.046 \\
$R w$ & 0.110 & 0.036 & 0.047 \\
$\mathrm{GOF}$ & 1.47 & 1.31 & 0.90 \\
\hline
\end{tabular}

${ }^{a} R=\Sigma\left\|F_{\mathrm{o}}|-| F_{\mathrm{c}}\right\| / \Sigma\left|F_{\mathrm{o}}\right| . \quad{ }^{b} R w=\left[\left\{\Sigma w\left(\left|F_{\mathrm{o}}\right|-\left|F_{\mathrm{c}}\right|\right)^{2}\right\} / \Sigma w F_{\mathrm{o}}{ }^{2}\right]^{1 / 2}$.

\section{Reference}

1) Siemeling, U.; Vorfeld, U.; Neumann, B.; Stammler, H. -G. Organometallics, 1998, 17, 483-484. 